\title{
Colourants made from aphids and ivy gum
}

Nabil Ali*

\begin{abstract}
The purpose of this study was to determine whether workable flesh-toned paints can be made from colourants from aphid insects and ivy gum using medieval gum and scale insect recipes. The processes of extracting pigment from the lesser-known ivy, wormwood and the giant willow aphids were explored, whilst paint binder and colourant was obtained from ivy plant gum. This work follows on experiences applying past practices derived from painters'to illuminators' technical manuals using similar processes once used for making colourants from historical scale insects, such as kermes and cochineal. The experimental reconstructions created by using selected locally sourced aphid insects and ivy gum, indicate that an aphid-stain and dye-based colourant which was fixed to calcium carbonate can form a successful paint source.
\end{abstract}

Keywords: Medieval painters' and illuminators'recipes, Aphin dye, Ivy gum, Medieval manuscripts, Flesh tone paint

\section{Introduction}

This study suggests plausible evidence for producing flesh tone paints from aphid insect dyes and explores the process of extracting pigment from these lesser-known insects, as well as obtaining gum and colourant from the ivy plant (Hedera helix). A central aim was to examine if usable colourants can be made with locally sourced ingredients using past practices derived from painters' to illuminators' technical manuals.

The ivy aphid was first observed and accidentally crushed by the author, when large aphid colonies were hosting on the ivy plant that the author was using to explore processes to extract ivy gum using the LDA recipe $\$ 1$.9.3A (see below and Fig. 2b). The visible red colour associated with the crushed insect raised the question of whether these insects would ever have been processed or used as a pigment in past practices and led to the idea of exploring whether a colourant can be made using locally sourced insects.

In fact, the giant willow aphid (Tuberolachnus salignus) which is one of the largest aphid species in the world, had been researched as a potential dye source for military uniforms [1]. However, this colourant can gradually change from a crimson-purple to a brownish colour when exposed to daylight (Fig. 3g). It had also been noticed that several smaller aphid species such as the Schizoneura lanigera (Eriosoma lanigerum)-also known as American Blight-which hosts on apple trees, have pronounced characteristics for producing a crimson dyestuff, but also can be fugitive to light [2] showing similar fading properties as the dyestuff made from the cochineal insect [3] ${ }^{1}$.

The red goldenrod aphid (Uroleucon nigrotubeculatum) feeds on the stems of the goldenrod plant (Solidago genus). It has been the subject of experimentation and used by Sara Kadolph, a textile artist and educator from North America. She has used locally sourced aphids for dyeing silk, by creatively crushing the whole insect onto fabric surfaces leaving a distinctive dark aphid stain [4]. While her processes differ from paint-making techniques inspired by historical recipes which are described in this work, nevertheless her work demonstrates the usefulness and applicability of using aphid-based dyes.

Past studies on dyes from aphid insects were carried out in the 1950s and 1960s by Cameron and Lord Todd and resulted in a number of publications, such as 
The Colouring Matter of the Aphididae [5]. Their work focused on isolating the compounds in the giant willow and bean aphids to understand the structure and stereochemistry of the proto aphins, rather than outlining practical applications for producing an alternative paint. However, their investigations established an overview and understanding of the key components present in selected aphid insects.

The chromophore group contained in aphids is naphthoquinone, with the most important element being perylene quinone obtained from the protoaphin-sl compound $\left(\mathrm{C}_{36} \mathrm{H}_{38} \mathrm{O}_{16}\right)$. This is present when the giant willow aphid (Tuberolachnus salignus) is crushed under neutral conditions [5]. The wormwood aphid (Macrosiphoniella absinthii) contains the acetylfluoraphin compound $\left(\mathrm{C}_{23} \mathrm{H}_{24} \mathrm{O}_{11}\right)$ and the 2-hydroxyemodin compound $\left(\mathrm{C}_{15} \mathrm{H}_{10} \mathrm{O}_{6}\right)$ is found in the ivy aphid (Aphis hederae) [6].

In the 1970s the complex chemistry of aphids was explored by Brown who listed and analyzed 80 individual aphid species outlining their secondary compounds, chemical structure and their characteristic aphin dye [6]. Brown highlights individual pigments relating to each distinctive insect in his scientific overview, which included the skeletal chemical formula of the studied species for identifying the insect's unique compounds. His work was essential for recognizing which specific dye compositions are linked to each individual aphid.

The perspective in this study derives from a creative practitioner producing colourants from a variety of potential sources using methodologies and ideas that may be unlike those used by a research scientist. Consequently, an additional goal of this work is to bridge the gap between the creative arts and the 'hard' sciences, hopefully to encourage and value other ways of thinking within the complexity of the modern world. It is argued that to have an artist's opinion during the preparation of materials and whilst working with them is both necessary and important, since these steps are closely connected to the creative discipline where they originate which contrasts with a singularly scientific approach. This is especially true when the work is associated with chromatic mediums and past craftsmen's knowledge from different cultures. While the existing aphid and ivy colour research may be minimal, making paint from these unfamiliar materials can indeed be achieved through the inspiration of artistic practices which have been translated from historical sources.

The central question which this study considers is whether aphid insects had ever been used in past practice to form locally sourced colourants as alternatives to the commercial use of the well-known kermes or cochineal insects. And if so, in what compositions would they have been used? Were the self-sufficient medieval monks that illustrated and copied illuminated manuscripts aware of the potential of these small insects colonizing their trees and plants and did they ever attempt to make experimental colourants from them? These questions are very difficult to validate due to insufficient historical evidence and texts to enlighten these questions. If European monks before or even after c. 1200 decided to formulate aphidbased pigment out of curiosity as an experimental stain rather than seeing them as just pests, is difficult to know, since the historical evidence may well have been reduced to ashes due to the desecration of the monasteries' illuminated books and artworks in the years of the Reformation that swept across the Kingdom of Christendom.

Indeed, if aphid-based colourants were ever used and are still hidden away in libraries on the pages of old manuscripts, the evidence of their use may still be difficult to ascertain, since these fragile dyes would be subject to deterioration like so many other organic dye-based pigments used by past craftsmen in many cultures.

\section{Historical insect recipes}

Even though there has been no historical evidence found to suggest that aphids were used for colourants in past practice on manuscripts or other objects, this work explores the ivy aphid (Aphis hederae); the wormwood aphid (Macrosiphoniella absinthii) and the giant willow aphid (Tuberolachnus salignus) and processed into paint sources as an alternative to the more commonly known scale insects that are evidently recorded in historical recipes. Well known scale insects included the kermes insect (Kermes vermilio) which contains the colouring agent kermesic acid $\left(\mathrm{C}_{16} \mathrm{H}_{10} \mathrm{O}_{8}\right)$, the cochineal insect (Dactylopius coccus) containing carminic acid $\left(\mathrm{C}_{22} \mathrm{H}_{20} \mathrm{O}_{13}\right)$ and the secretion from the lac insect (Kerria lacca, Laccifer lacca, Carteria lacca, Tachardia lacca, Lakshadia lacca, and the Chinese lac: Kerria chinensis) containing laccaic acid $\left(\mathrm{C}_{26} \mathrm{H}_{19} \mathrm{NO}_{12}\right)$ which belongs to the chromophore group anthraquinone [7, 8]. For this work, experience with producing colourants from these better known dye sources was essential for experiments to produce the aphid-based colours.

The kermes insect has been well-known as a source for red dye since classical times and was reported in earlier periods in the Arab and Indian cultures for colouring silk. Commercial trade agreements between Bologna and Ferrara date back as early as the late twelfth-century with the cities of Venice and Florence famously known in the fourteenth-century for their brilliance in dyeing cloth. In past practices indirect dyeing techniques were commonly utilized by textile shearings dyed with kermes which was then precipitated with alum to form the colourant [9]. Colourants were also made from carminic acid found in a number of 
cochineal insects, the (Dactylopius coccus) mentioned above as well as the Armenian cochineal insect (Porphyrophora hamelii) and the Polish cochineal insect (Porphyrophora polonica). The Polish cochineal feed on the roots of the perennial knawel (Scleranthus perennis) [10] whereas the South American cochineal, which have a lower amount of carminic acid [7], fed on the prickly pear cacti (Opuntia Ficus-indica). Dye from the new world Mexican cochineal insect were introduced to Europe in the early part of the sixteenth-century and became the more favorable dyestuff than using the old world kermes which started to decline [8].

Dating from the ninth to late twelfth-century, the Mappae Clavicula family of manuscripts, mentions several dye recipes which combine other ingredients with kermes such as vermillion, cinnabar and indigo (azure) [11].

The dyestuff made from kermes to the cochineal insects have a stronger tinting strength than the aphid insect dyes. Rather than being prized for their ability to produce colour, aphid insects were viewed as crop pest in medieval periods [12]. As a result, there were efforts to protect crop production by attempting to eliminate the aphids using organic sprays consisting of strong vinegar heated with the deadly henbane plant (Hyoscyamus niger) thus producing a lethal medieval pesticide [13].

Montpellier recipe $\$ 1.11 .2 \mathrm{~A}$ transcribed below, explains the process for making a red colourant using kermes insects, also known as 'grain' [14], heated in gum water with the addition of alum. Recipe $\$ 8$ from the Beinecke MS 163 also transcribed below, describes adding kermes to change white wine into a favorable rose colour. These historical recipes were used as guidelines for replicating similar processes but substituting aphids as an alternative to kermes insects. The experiments in this study adopt similar ideas to those of Buckton of adding high alkaline solutions to enrich the aphid dye by making it brighter, which he had noted for the woolly apple aphid [2].

Recipe §1.11.2A. Montpellier, University Library, MS H 277. (c.1400) [14]

\begin{tabular}{ll}
\hline Translation & Latin text \\
\hline [\$1.11.2A]_Preparation. take the & {$[\$ 1.9 .3 \mathrm{~A}]$-Confectio. accipe granam } \\
best'grain' [kermes] and grind it & optimam et molle bene in mortario/ \\
well in a mortar, then put it in a & postea pone in coclea cucula vel in \\
shell or in some other clean vessel & alio vase nitido et accipe aquam \\
and take gum water [arabic] and & gummi et pone in granalet pone \\
put it into the grain, and put in it a & intus de alumine parum et pone \\
little alum and put it over embers & super prunas et permitte bulire \\
and let it boil on a slow fire until it & lento igne donec habeat optimum \\
shall have the best colour & colorem
\end{tabular}

Recipe §8. Yale, University Library, Beinecke MS 163. f.122v123v. (c.1450) [15]

\begin{tabular}{|c|c|}
\hline Translation & Middle English text \\
\hline $\begin{array}{l}\text { [§8] _ For to give a tun [barrel, cast] } \\
\text { of white wine a good colour: }\end{array}$ & $\begin{array}{l}\text { [\$8]_For to geve a tonne of white } \\
\text { wyne gode colour: }\end{array}$ \\
\hline $\begin{array}{l}\text { Take half a pound [230 grams] of } \\
\text { kermes that people grain-colour } \\
\text { scarlet [things] with and pound it } \\
\text { fine and mix with clean water and } \\
\text { put it into a clean vessel and let it } \\
\text { lie } 8 \text { or } 9 \text { days before you draw any } \\
\text { wine out [of the barrel], and soon } \\
\text { after it shall be a fine rose colour }\end{array}$ & $\begin{array}{l}\text { Take halfe a pounde of Grayne that } \\
\text { men grayneth wyth scarlet ande } \\
\text { pounde hym smale and medle hym } \\
\text { of clene watir and put hit in-to a } \\
\text { clene vessell and late hym lye viij of } \\
\text { ix daies or that thu drawe any wyne } \\
\text { therof and sone aftir he shalle a fyne } \\
\text { rose coloure }\end{array}$ \\
\hline
\end{tabular}

\section{Historical ivy recipes}

Recipes using ivy gum can be found below in several medieval treaties: The Montpellier manuscript, University Library, MS H 277, also known as the Liber diversarum arcium (LDA); the Rawlinson manuscript, Oxford, Bodleian Library, MS Rawlinson C.506. f.324v and the MS Cotton Titus D.XXIV manuscript in the British Library.

The LDA describes techniques to extract red gum from the common ivy plant (Hedera helix), by "piercing ivy shoots in spring" [14]. Several other recipes similar to the LDA are available, one of which is the De coloribus et artibus Romanorum manuscript (British Library, Egerton $840 A$ ) which was written by the Italian author Heraclius and most likely dates from the tenth-century CE. Two others are the northern European twelfth-century manuscript (MS Harley 3915); and the fourteenth-century Liber de coloribus illuminatorum sive pictorum (Sloane 1754) [14].

Although it can be difficult to establish where the ivy recipes originated, it is plausible that ivy extraction methods pre-date both Christian and Islamic cultures or many other traditions from the same period due to evidence from earlier cultural texts that suggests using the material. For instance, ivy juice is mentioned in an earlier medicinal text written by the second-century CE Greek physician Aretaeus the Cappadocian, who prescribed its usage as one of many plant juices to deal with hysteria and fits of delirium [16]. We cannot be certain if Aretaeus original meaning was to prescribe the extracted ivy gum as mentioned later in medieval recipes, or if it was simply the pressed juice from the ripe ivy berries, or a cocktail of both? Yet he does state the juice can be an added ingredient in a remedy for treating madness and brain disorders. Another first-century Greek physician and botanist, Dioscorides-notable for his book De materia medica-also explains that ivy was an additive ingredient for medicinal wine treating headaches and dysentery by cooking the leaves with ivy berry clusters supplied as a liquid medicine [17]. This clearly suggests that the plant's practical use-whether for experimental medicine or factual knowledge-was established in ancient medical 
practices and in all likelihood, may have been copied over the centuries and compiled in different manuscripts to find their way into the earliest commentaries on how to obtain ivy gum or juice.

It must be pointed out that close connections between artists' recipes, the production of pigments and doctor dispensaries were indeed known to have existed throughout the Middle Ages and it is not unusual to find recipes written on the same page appearing next to one another in unrelated chapters describing and using useful materials to obtain colour [14].

The two recipes transcribed below, originally written in Latin and Middle English, respectively, describes a method to obtain ivy gum. They have been translated into modern English by Mark Clarke and gives insight into how to retrieve using a preparation processes, rather than the practical applications of using the already obtained gum.

In this study, the recipes were used only as a guideline to reconstruct experimental paint processes for obtaining the gum, by following the same time of the year when the sap rises through the ivy and many other plants. There are many more ivy recipes mentioned in a range of other manuscripts, yet generally speaking the processes are comparable to one another and also similar recipes might have been copied from the same earlier manuscript, which may now be lost or destroyed.

Recipe §1.9.3A. Montpellier, University Library, MS H 277. (c.1400) [14]

\begin{tabular}{lc}
\hline Translation & Latin text \\
\hline [\$1.9.3A]_Preparation. Manufac- & {$[\$ 1.9 .3 \mathrm{~A}]$ _Confectio. Sinopel autem } \\
tured sinopel, on the other hand, & facturus sic facit, marcio mense, \\
is made thus: in the month of & cum omnia genera herbarum \\
March, when all types of plants & sucum a terra recipiunt, edera, \\
receive sap from the earth, pierce & subola, vel aculo tantum perforetur, \\
ivy shoots slightly with an awl or & et egredietur liquor gummi qui \\
pin, and a gum liquor will emerge & vocatur gummi edere, \\
which is called 'ivy gum,', & hic cum urina coquatur, et erit \\
this is cooked with urine, and will be & sanguineus color qui vocatur lacha, \\
a sanguine colour which is called & vel sinopel \\
lacha' or 'sinopel' & \\
\hline
\end{tabular}

Recipe \$43. Oxford, Bodleian Library, MS Rawlinson C.506. f.324v. (c.1400-1450) [18]

\begin{tabular}{|c|c|}
\hline Translation & Middle English text \\
\hline $\begin{array}{l}\text { [\$43]_-To make lake, go in March } \\
\text { or in April where ivy grows upon } \\
\text { oak, and take an axe and pierce } \\
\text { the stork of the ivy as many times } \\
\text { as you like; and then a month } \\
\text { afterwards, you shall see come } \\
\text { out of the same piercings a good } \\
\text { bright gum; } \\
\text { then take that gum and cook it well } \\
\text { in a new earthenware pan with } \\
\text { the urine of a man, for a good } \\
\text { while; and skim it well and then } \\
\text { you will see a good sanguine } \\
\text { colour; and then take it off from } \\
\text { the fire, and let it cool, and when } \\
\text { it is cold, pour out the thin [liquid] } \\
\text { above, and from the thick [mate- } \\
\text { rial] in the bottom make small }\end{array}$ & $\begin{array}{l}\text { [\$43]_-To make lake, go yn Marche } \\
\text { oryn Aprill ther yvy growyth uppon } \\
\text { oke, and take an axe and schoch } \\
\text { the storke of the yvy as many of as } \\
\text { thu lyst, and than in a month aftyr } \\
\text { thu schalt se come owt of the same } \\
\text { schocchis fayre bryght gumme; } \\
\text { than take that gumme and sethe it } \\
\text { well in a newe erthen panne with } \\
\text { uryn of a man a good while, and } \\
\text { skyme it well, and than thu schalt } \\
\text { se a fayre sangwyn colour, and then } \\
\text { take it fro the fyre and lat it kele, } \\
\text { and whan it ys colde powre owt the } \\
\text { thynne above, and of the thycke in } \\
\text { the bottom make small pelettes and } \\
\text { drye hem yn the sonne and that } \\
\text { schall be good lack }\end{array}$ \\
\hline
\end{tabular}

pellets, and dry them in the sun: and that shall be good lac/lake

The process to extract ivy gum is explained in greater detail in the fifteenth-century Middle English recipe $\$ 43$, from the Oxford, Bodleian Library, MS Rawlinson C.506. It gives a clear detailed description on how to extract gum from the stems of the ivy plant rather than including a direct explanation for its practical use. Earlier recipes-which have been explored by Christoph $\mathrm{Krekel}^{2}$-indicates that the gum may have been used as a technological product applied for waterproofing or staining leather items and book covers [19]. An example of this was documented in the Anglo-Norman manuscript from twelfth-century England (British Library, MS Cotton Titus D.XXIV) and gives reference to a dye recipe for staining and sealing leather cloth by preparing an alkaline solution with lime, brazilwood, 'ivy and plum gum' added with vellum glue then heated with potash lye [20]. Interestingly, this recipe explains adding the plant gums together in conjunction with other ingredients rather than firstly obtaining and preparing the raw material as described in the LDA and Rawlinson recipes.

\footnotetext{
${ }^{2}$ Chemist Christoph Krekel has successfully reconstructed the rare ivy gum colourant following selected medieval recipes translated by Mrs Merrified, Richards Thompson and the Benedictine monk Wolfgang Sedelius [19]. His practical outcomes differ from the experiments outlined in this study because his research was to reconstruct a 'blood-red' colourant using selected medieval recipes, rather than producing flesh tone paint made using ivy gum and aphids.
} 


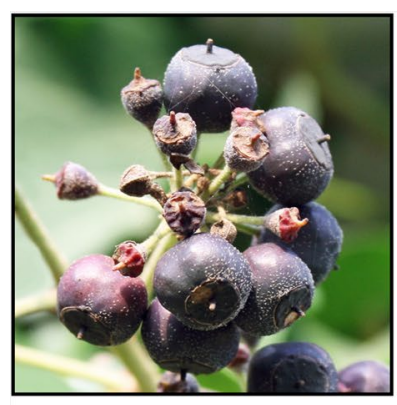

a

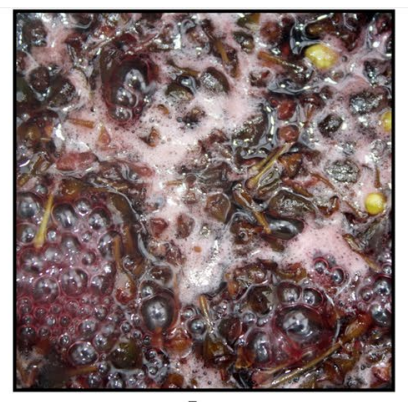

b

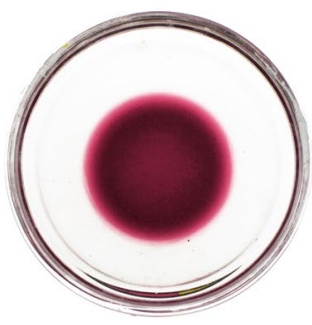

c

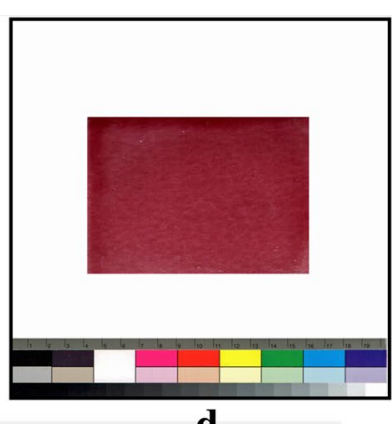

d

Fig. 1 a Ripe ivy berries in April. b Heating berries in clear wine and alum. c Filtered ivy berry dye. $\mathbf{d}$ lvy berry dye-paint using experimental methods - 3 layers

Recipe fol.131 r-132v. British Library, MS Cotton Titus D.XXIV. (c.12th) [20]

\begin{tabular}{ll}
\hline Translation & Anglo-Norman text \\
\hline [fol.131r]_For wreime, which is a & [fol.131r]_De wreime, ki est apeleit \\
moss: Let it be chopped up in an & mose: Seit mincét en un' escale, puis \\
eggshell and then add builder's & i meteiz de la chauz de muster. Issi \\
lime. This is done until it is seen & seit mi spur maurer desque il le vei[t] \\
to be properly matured. Then & bon. Puis seit prent parmi un drap. \\
strain it through a cloth. Take the & Pernezle alum sil metez en ewe, sil \\
alum, place it in water, heat it, put & caufez, si metezle quir enz primer, \\
the leather in first, then [put]- & puis le-[fol.132v] - brasil en ewe, \\
[fol.132v]-brasil in water and boil & sil bullez, e temper[z] lle de le lessive \\
it, and temper it with wood[-ash] & de fust, la gume de l'eire e la gume \\
lye, gum of ivy and plum gum & del pruner e glud de parchemin, de \\
and parchment and vellum glue & veelin, ulinement, sil metez en un' \\
in equal measure, place it in an & escale, sil metez utre le fu pur caufer \\
eggshell, and place over heat &
\end{tabular}

The fifteenth-century Le Bégue manuscript De Diversis Coloribus (Paris, Bibliothéque nationale de France, MS Latin 6741)_translated by Merrifield and originally written by Johannes Alcherius in the late fourteenthcentury-explains how to make a coloured lake to use for drawing and to dye animal skins using ivy juice [9]. The recipe also explains cutting ivy in March to use the juice, which could also imply using the 'ripe ivy berriesonce they have been cut from the vine in March-so that, 'blood-like' coloured dye is made to dye animal cloth, or for this study used to illustrate an experimental ink-based colourant (Fig. 1).

In recipe $\$ 43$, it specifies the same period to obtain ivy gum in March or April as suggested in the $\$ 1$.9.3A recipe and Le Bégue and highlights the methods by cutting the stem with an 'axe, instead of piercing it with an ' $a w l$ ' the tool used within the leatherwork trade [21]. This small detail may imply other craft professions being interested in collecting the same gum using similar puncturing techniques that were believed to work and indeed do. Recipe $\$ 43$ suggests returning after a period of 1 month once the stem had been pierced to collect the bright resinous gum bleeding from the plant's bark. Although, the gum can start to appear from the plant after several days from when the initial stem was cut. This recipe also provides an intelligible overview of when, where and how to extract gum by specifying the tree species the ivy clings to. Other ivy gum recipes have been explored in Krekel's work [19] which suggests alternative processing techniques in attempting to make red colourants having concluded with interesting results.

\section{Experimental-methods and results}

There are more than 6000 species of aphids worldwide [22]. If only $1 \%$ were found to produce a suitable colourant towards making a flesh coloured paint, this would consist of approximately 60 individual species. As described below, the author's experimental recipes were restricted to three different aphid species which were retrieved from the author's workshop garden. It was a useful exercise to establish whether the different aphid species used introduced any variation in the shades of the dye stuff produced.

\section{Ivy aphid-(Aphis hederae)}

For this experiment, hundreds of aphids were collected in late spring whilst they were still feeding on the stems of the ivy plant (Fig. 2a, b). The insects were placed into a double pan (bain-marie) with $28 \mathrm{ml}$ of clear wine $(\mathrm{pH}$ 3 ) then crushed with a spoon and gently heated for several minutes to release the red insect dyestuff. This replicates a similar process mentioned from recipe $\$ 8$ when adding the Kermes insect to white wine changing it into a rose colour [15]. $4 \mathrm{~g}$ of alum (potassium aluminium sulphate $\mathrm{KAI}\left(\mathrm{SO}_{4}\right)_{2}$ was added to intensify the brightness of the colour, then heating was continued until the mixture was reduced to $7 \mathrm{~g}(\mathrm{pH} 2)$. The dye was then sieved through a fine mesh. At this stage the red colour produced appeared similar to that made using historical 


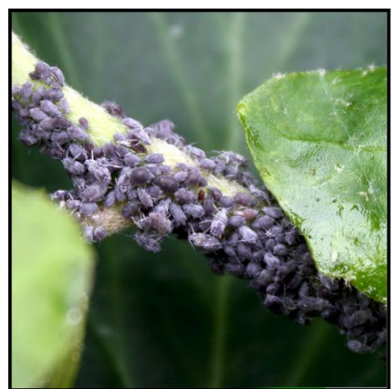

$\mathbf{a}$

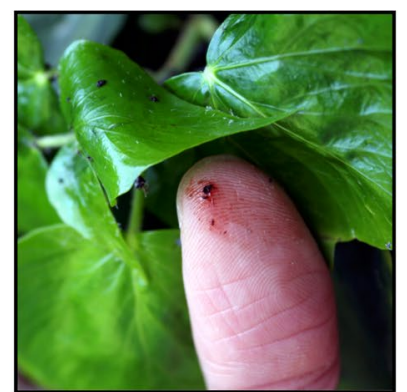

b

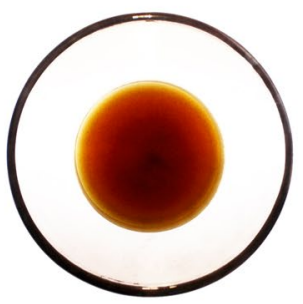

c

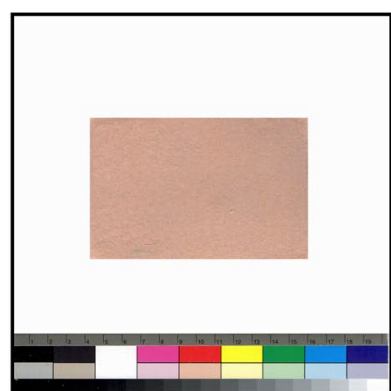

d

Fig. 2 a Colony of aphids feeding on the ivy plant (Aphis hederae). $\mathbf{b}$ The author noticing red juice from crushed ivy aphids. c Filtered aphid dye made with clear wine and alum. $\mathbf{d}$ Aphid dye paint-out

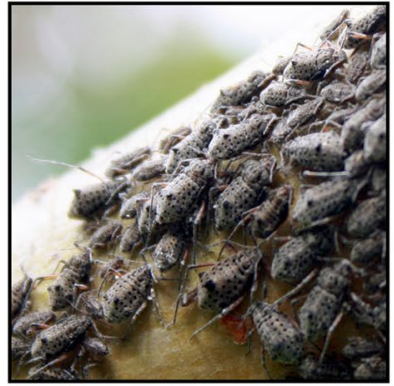

$\mathbf{a}$

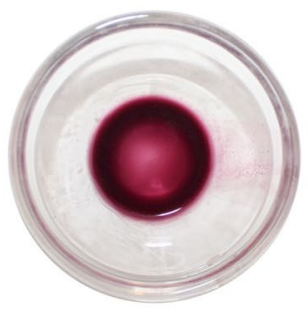

$\mathbf{e}$

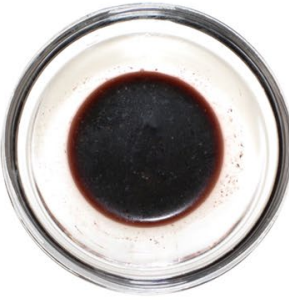

b

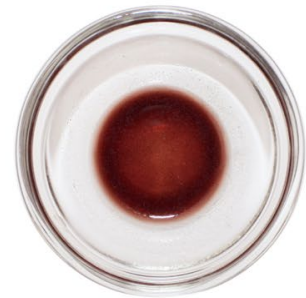

f

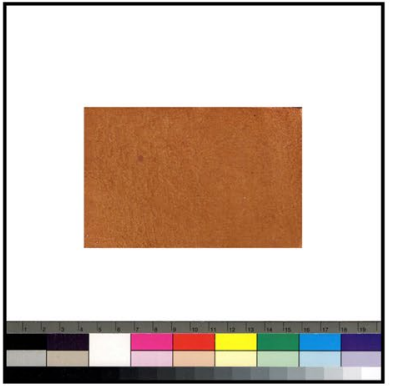

c

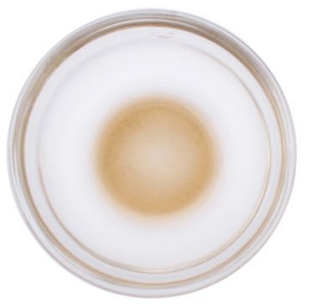

g

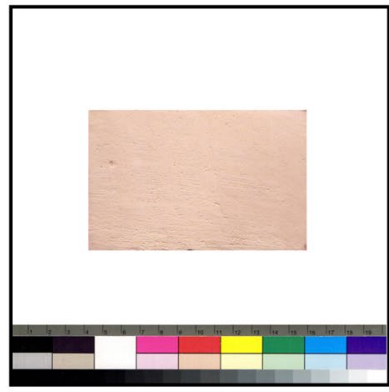

d

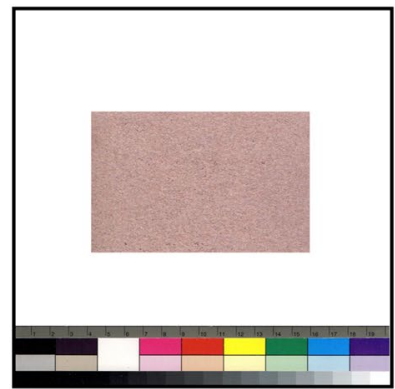

h

Fig. 3 a Large colonies of willow aphids (Tuberolachnus salignus). b Crushed aphids in water. c Aphid dye paint-out. d Aphid dye mixed with calcium carbonate paint-out. e Fresh aphid dye in potash water. f Aphid potash dye exposed to light for 2 days. $\mathbf{g}$ Aphid potash dye and potash exposed to light for 7 days. $\mathbf{h}$ Fresh aphid potash dye paint-out

recipes based on scale insects (Fig. 2c). However, when gum arabic was added to the aphid dye made with clear wine, alum, vinegar or urine, it changed from a reddish shade to a mid-brown colour losing its initial vibrancy.

\section{Giant willow aphid-(Tuberolachnus salignus)}

Hundreds of giant willow aphids were collected in October from a large colony feeding on a Corkscrew willow tree (Salix matsudana-Tortuosa) with the entire insects crushed in $5 \mathrm{ml}$ of water (pH 5). Small amounts of water were used for this experiment because the dye was not heated nor reduced, but left to stand for several minutes before it was sieved through a fine mesh. This produced a deep purple-red aphin dye and was then added to $1.5 \mathrm{~g}$ of calcium carbonate $\left(\mathrm{CaCO}_{3}\right)$, then mixed for several minutes in a small pestle and mortar to form a reasonable pinkish paint that could be used for flesh tones (Fig. 3d). 


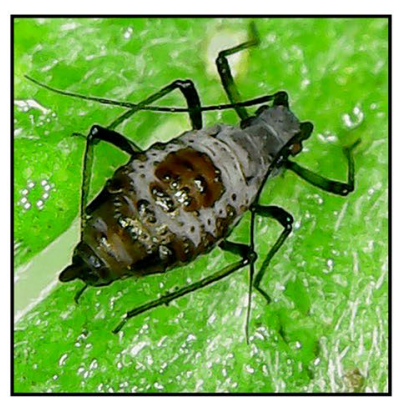

a

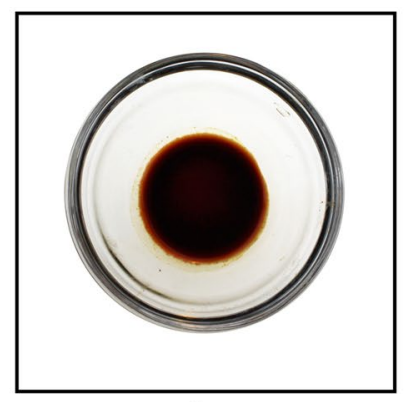

b

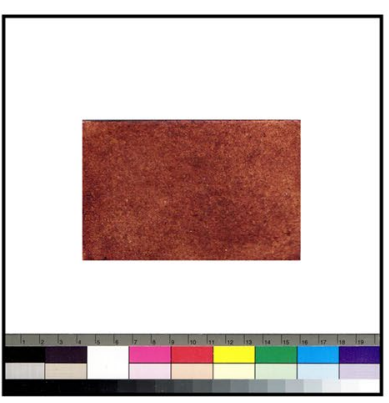

c

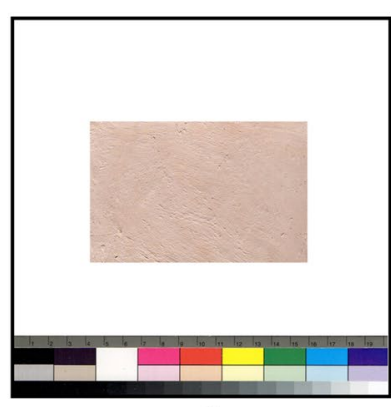

d

Fig. 4 a Wormwood aphid (Macrosiphoniella absinthii). b Crushed aphids in water. c Colour directly from aphids. d Aphid dye and alum mixed with calcium carbonate paint-out

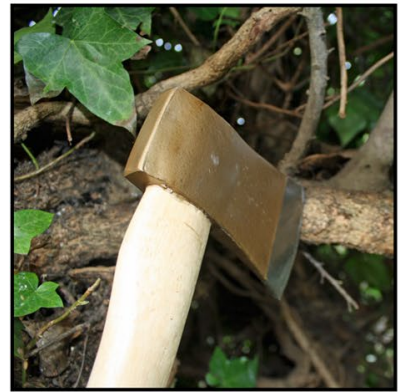

a

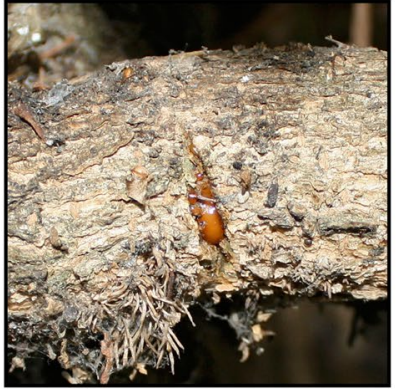

b

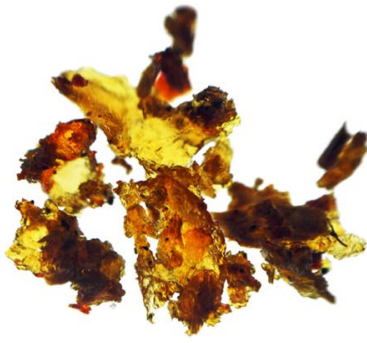

C

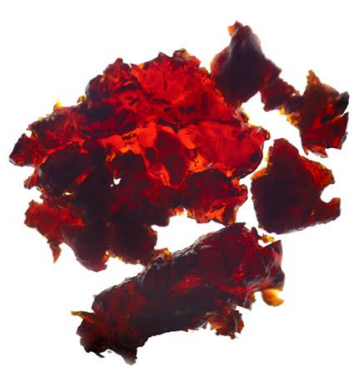

d

Fig. 5 a Making cuts with an axe. b Ivy gum after 3 days. c Fresh ivy gum after 1 month (actual size 5 mm). d Ivy gum after 1 year in storage (actual size $5 \mathrm{~mm}$ )

It has been observed in the late nineteenth-century when Buckton stated that adding caustic potash or lye [potassium hydroxide $(\mathrm{KOH})$ ] to aphin dye extracted from the pine tree aphid, produces a fine crimson colour [23]. The potash method was adopted and reconstructed using the localized giant willow aphids, firstly by crushing the entire insect in $5 \mathrm{ml}$ of cold water (Fig. 3b), then adding $1.5 \mathrm{~g}$ of potassium carbonate $\left(\mathrm{K}_{2} \mathrm{CO}_{3}\right)$ to deepen the dye making it more alkaline $(\mathrm{pH}$ 14 ), which produced a brighter crimson and a good colour tone (Fig. 3e, h). However, the dye when exposed to natural daylight, decolorized quickly over a period of 7 days, thus making it a poor quality dyestuff (Fig. 3f, g).

\section{Wormwood aphid-(Macrosiphoniella absinthii)}

In Autumn, a large colony of aphids feeding on the wormwood plant (Artemisia absinthium) were collected and the entire insect was crushed in $3 \mathrm{ml}$ of water ( $\mathrm{pH} \mathrm{5)}$ with a very small amount of alum added to the dyestuff (Fig. 4). After been sieved, $2 \mathrm{ml}$ of dye was added and mixed with $1 \mathrm{~g}$ of calcium carbonate
$\left(\mathrm{CaCO}_{3}\right)$ and only for this recipe, several drops of liquid gum arabic was added to form a rose coloured paint (Fig. 4d).

\section{Ivy gum-(Hedera helix)}

The ivy recipes were reconstructed following recipes $\$ 43$ and $₫ 1.9 .3 \mathrm{~A}$ as a guideline. This was to evaluate the effectiveness of the extracting process and to visually compare the dye made from the aphid insect with the extracted gum resin when made into a flesh-toned paint.

In April, cuts were made to the stem of a mature ivy plant measuring $25-40 \mathrm{~mm}$ in diameter, by piercing the outer bark with an axe (Fig. 5a). After 3 days, pale yellow gum emerged from the wounds of the stem with small amounts collected over the period of 1 month (Fig. 5b, c). The ivy gum ( $\mathrm{pH} 4)$ was then placed into a small pan of $50 \mathrm{ml}$ of urine $(\mathrm{pH} 8)$, then gently heated reducing the liquid to $17 \mathrm{ml}$ eventually leaving the gum to naturally dry.

To discourage the flies that were attracted to the smell of urine, smoke sticks were made from locally sourced materials from the author's workshop garden. They were 


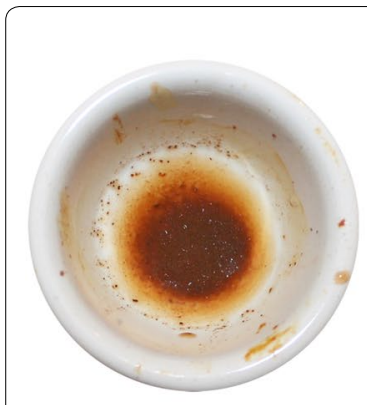

a

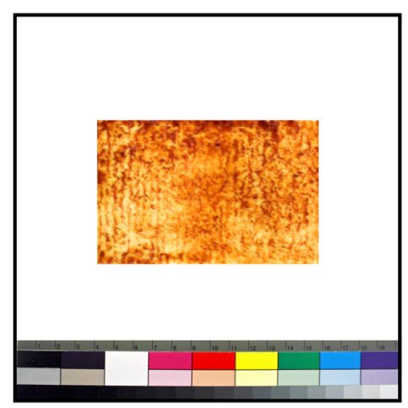

b

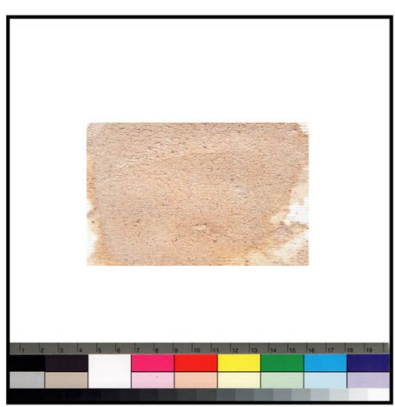

c

Fig. 6 a Old encrusted ivy gum diluted in vinegar. b Fresh raw ivy gum paint-out. c Ivy gum mixed with calcium carbonate paint-out

constructed using rosemary sprigs (Rosmarinus officinalis), sage (Salvia officinalis) and the pungent leaves of the wormwood plant (Artemisia absinthium) and when burnt, had similar repellent properties as smouldering myrrh from the genus Commiphora tree that's native to Africa and Southwest Asia [24]. As described in the LDA, adding myrrh as an additive ingredient to repel flies when preparing recipes using egg glair, was indeed a common practice in certain paint preparations [14]. However, using smokes sticks for this particular purpose, rather than burning or even adding myrrh to the recipe-which could alter the colour characteristics of the recipe if applied directly-presents the author's thinking for locally sourcing alternative materials which could be used as sufficient workable substitutes-if at all possible-with neither more, nor less practically effectiveness, than materials which may be expensive or indeed scarce to acquire. Whereas fencing oneself inside a net screen-house to form a barrier against flies could be implemented, it negates the physical motion and the all-inclusive perception when working in an exterior art workshop. Therefore, using and making smoke sticks are a personal preference which has practical functions.

The small amounts of ivy gum collected from the previous season had naturally deepened changing from an orange to a reddish colour over a 12-month period (Fig. 5d). This gum was heated in urine and became increasingly duller losing its original brightness. However, while heating the fresh orange-coloured gum in urine did cause it to become darker, it still retained its original colour intensity. Both gum samples were insoluble. The old resinous red gum, however, did become soluble when it was added to acetone producing the distinctive orange rusty colour described previously in Krekel's research where he had produced a rusty orange paint firstly by crushing the ivy gum then mixing it with a gum arabic binder [19].
It is plausible that clear vinegar could have been used in past practice to reactivate old resinous gum to form a workable paint source, since vinegar is mentioned in $L e$ Bégue's fifteenth-century 'sinopis de mellana' recipe [9]. It is written in medieval technical manuals that vinegar is frequently used as an additive and effective medium to develop paint colours, which are described in recipes from the LDA manuscript [14]. As explained in this work, old and new ivy gum can become soluble when added to clear vinegar ( $\mathrm{pH}$ 1) (Fig. 6a, b) which helps to liquefy the gum before it is added to calcium carbonate.

The diluted ivy gum in clear vinegar $(\mathrm{pH} 1)$ was mixed with calcium carbonate and produced a natural flesh tone paint (Fig. 6c). Comparing the rusty-orange colour made directly from the raw ivy gum (Fig. 6b), by mixing the diluted gum with calcium carbonate $\left(\mathrm{CaCO}_{3}\right)$ it was revealed to have an ideal quality for producing a suitable paint source useful for detailed work. For this practical reconstruction, only a small amount of ivy gum measuring $5 \mathrm{~mm}$ square was needed to make sufficient amounts for painting a sample. Therefore, retrieving fresh and old encrusted gum that forms on past ivy injuries, would indeed be achievable for creating a flesh-toned paint and could ideally be collected over a length of time to be stored away for later use.

\section{Mixing ivy gum with giant willow aphids}

Old encrusted ivy gum was experimentally mixed with poppy-seed oil-due to the oils pale and clear character in revealing the true colour of the gum-then left to soak for several months resulting in a free radical chain reaction to form a flexible rubbery-gum (Fig. 7a) [25]. The rubbery-gum was then soaked in clear vinegar making it expand and swell twice its original size (Fig. 7b). It only became soluble in this state when it was mixed with $2 \mathrm{ml}$ Isopropanol $\left(\mathrm{C}_{3} \mathrm{H}_{8} \mathrm{O}\right)$ (Fig. 7c). Isopropanol has better dissolution properties than ethanol for fats and oils and for dissolving natural resins. It is widely used in the 


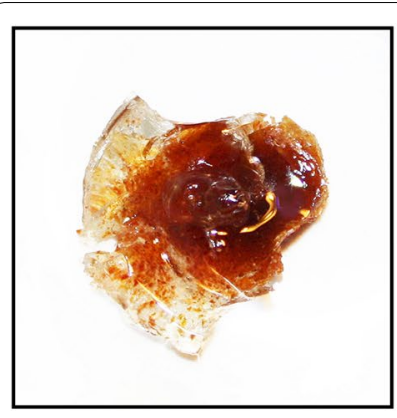

a

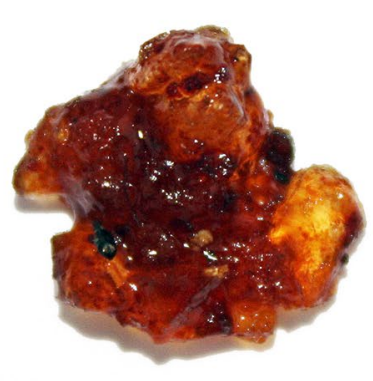

b

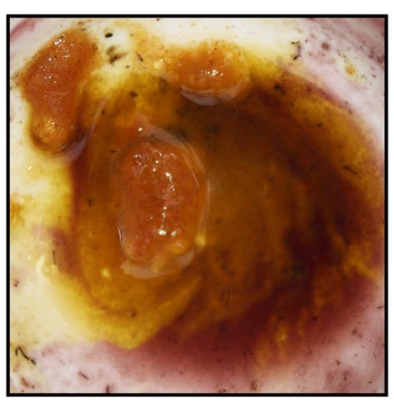

c

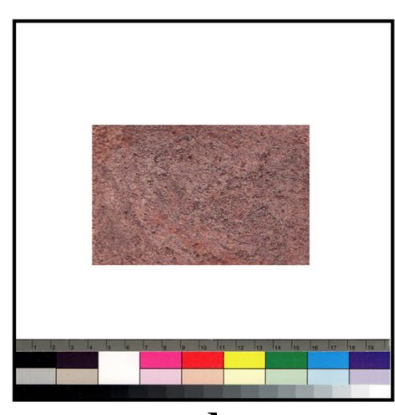

d

Fig. 7 a Ivy rubbery-gum. b Expanded ivy rubbery-gum caused by adding clear vinegar. c lvy rubbery-gum mixed with Isopropanol alcohol then mixed with aphid dye. $\mathbf{d}$ Paint sample on chamois leather

paint and ink industries for recrystallization and extraction [26]. The rubbery-gum was then added to freshly crushed willow aphids which were prepared in a $2 \mathrm{ml}$ Isopropanol based solution (keeping both liquids consistent), the solutions were mixed and filtered through a fine mesh. Both the liquid rubbery-gum and aphid-dye were ground together in a small pestle and mortar, adding $0.13 \mathrm{~g}$ of calcium carbonate $\left(\mathrm{CaCO}_{3}\right)$ and $0.06 \mathrm{~g}$ of potash $\left(\mathrm{K}_{2} \mathrm{CO}_{3}\right)$ in producing a purple paint that was applied to the surface of chamois leather (Fig. 7d). Purple would also be a suitable tone for shadows in contrast to fleshtones. However, the experimental colour even when it is not exposed to natural daylight, decolorized very quickly over a short period time indicating that it is very unstable (Fig. 8-no. 7).

Applying simple techniques in making dye is effective when mixed with calcium carbonate or a gesso substrate to form a workable pigment that can be retained for later use. This fixing process to produce dye-based paint was described by the Roman architect Vitruvius in the firstcentury BCE [27]. He gives examples for making organic dyestuff more manageable by storing dye colours in pigment form using a calcium carbonate substrate. This clearly indicates that organic dyes were not used only for colouring textiles-as is commonly presumed-but were formulated by precipitation onto other substrates for making organic paint systems using a multitude of plants and insects. Other medieval techniques additionally used to store dye were clothlets, a cloth soaking method used for almost any vegetable dye for future application and documented in the Latin De arte illuminandi (Naples, Biblioteca Nazionale Vittorio Emanuele II. MS Latin XII.E.27) [28] and in Cennino d'Andrea Cennini's book (Florence, Biblioteca Medicea-Laurenziana, MS. Plut.78.23).

\section{Flesh tones}

Flesh tone recipes are well documented in range of medieval manuscripts where their use follows the subject matter and complex painting systems. These recipes are found in the Mappae Clavicula family of manuscripts (Lucca, Biblioteca Capitolare Feliniana, Codex 490; Sélestat, Bibliothéque Humaniste, MS 17; and the PhillippsCorning Manuscript, Corning Museum of Glass (Corning NY), Rakow Research Library, MS.5) dating from the ninth to late twelfth-century with some recipes dating back even earlier [14]. The Mappae Clavicula presents paint recipes that could be used to make multiple colour compositions under the heading 'panius pigment' [11]; modelling techniques that were part of a highly disciplined paint system. Theophilus' also notes many flesh tone recipes using established pigments in his twelfth or early thirteenth-century craft treaties: De diversis artibus (London, British Library, MS Harley 3915), when describing how to paint faces and naked bodies [29]. Cennini's well-known fifteenth-century Craftman's Handbook also details how to paint flesh for the living and to avoid using any pinks for the lifeless dead [30].

Further examples can be found in the $L D A$ and in the copy of the Strasbourg manuscript (the original early fifteenth-century edition was destroyed by fire in 1870) [31]. These recipes explain alternative methods to create flesh tones used for painting the young, old, and various skin colours, with additional examples found in the fifteenth-century Bolognese Manuscript-Segreti per Colori (Bologna, Biblioteca Universitaria, MS. 2861) [9]. Paints were applied in an involved layering system due to the rich vocabulary used for creating images for manuscripts, panels or walls. Colourants include earth pigments, azurite, copper greens, vermilion, lead white, orpiment and many organic pigments made from saffron, woad, and the kermes insect [32]. Combinations of inorganic and organic sources were also evident, such as 


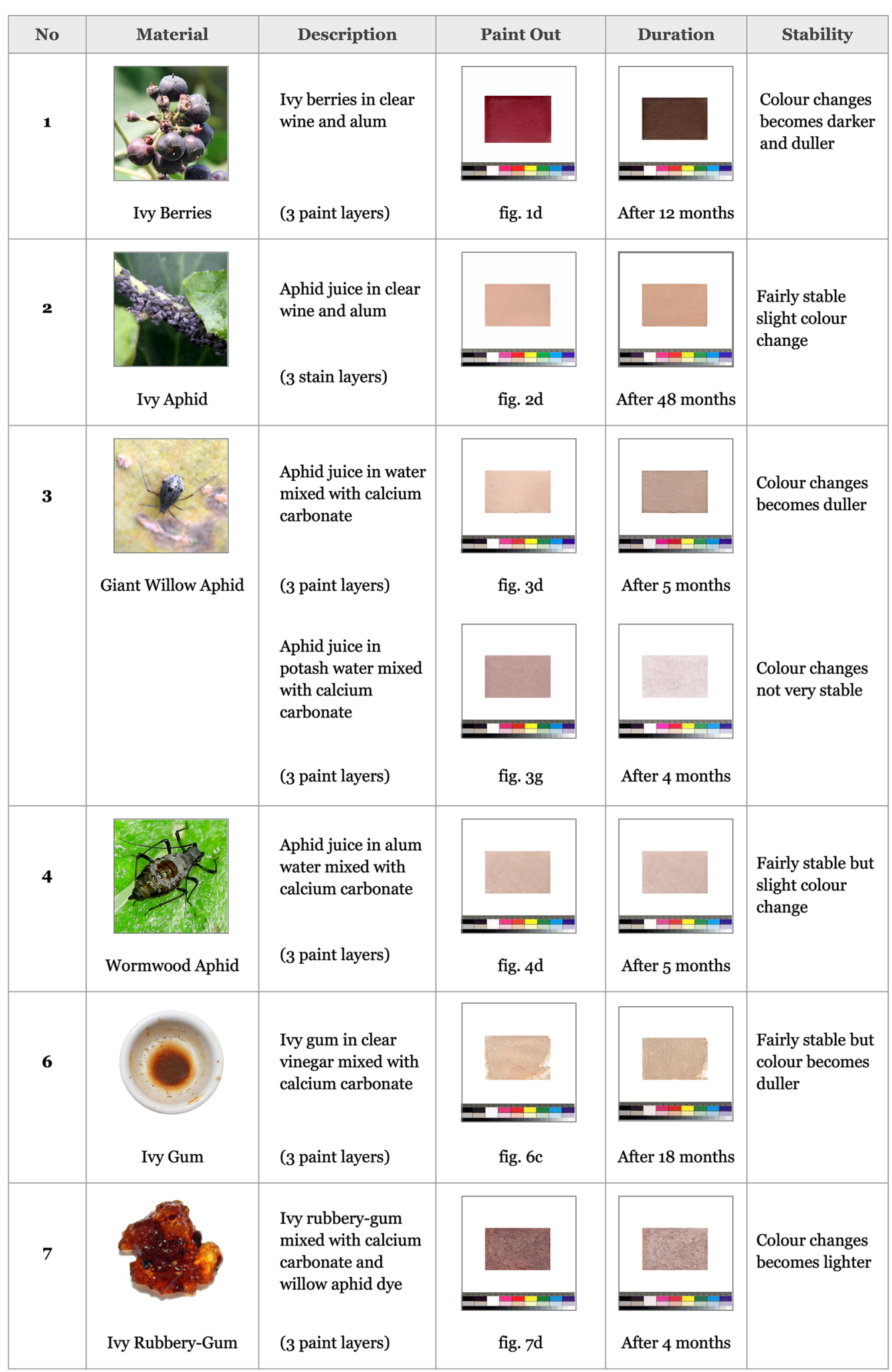

Fig. 8 Lightfastness test of paint samples by real-time ageing 
the instructions to use stamens from the common poppy plant (Papaver rhoeas), which is mixed with a cinnabar pigment to make a purple colour for shadowing [31].

The composition of the pigments and techniques used to build final flesh tones are embedded within the hidden detail of the painting. When we consider the colours that were described in some technical manuals, for example making a rose coloured flesh-tone using ivy gum, or indeed the alternative aphid insect, mixed with a little calcium carbonate, we realize that these practices have yet to be studied in detail and evidence for them has not been explored using scientific analysis on artefacts. To prove their presence in historic artifacts can be very challenging due to the limitations of analytical methodologies, which will be explained below and being aware if such materials were ever implemented for this actual purpose.

\section{Analytical methodologies to identify organic pigments}

It must be pointed out that identifying organic colourants in illuminated manuscripts or other artefacts by non-invasive analytical techniques, has in the past been very difficult. For example, paint layers on the pages of books are relatively thin compared to paint on murals, easel paintings or sculptures, where the paint is often much thicker. Removing fragments from manuscripts by micro-destructive techniques which can leave microscopic but irreversible damage, is considered problematic in the field of cultural heritage conservation [33]. Fortunately, there are many non-invasive techniques that can be applied to detect organic dyes and pigments such as UV-Visible spectrometry (UV-Vis), and Thin Layer Chromatography (TLC) combined with UV-Vis, and Infra-Red Spectrometry (IR). In one example, a spectroscopic technique, Coupled Steady-State were applied to measure pigments and dyes used in the ninth-century Book of Kells (Dublin, Trinity College Library, MS 58). This was to confirm which pigments were present on the manuscript [34]. However, not all of the organic pigments which were originally used on the Book of Kells could be identified through the analysis, therefore, leading to further research being undertaken using combined Fourier transform infrared spectroscopy (FTIR) and energy dispersive X-ray fluorescence spectroscopy (XRF) [35].

3D-Fluorescence Spectroscopy, another sophisticated non-invasive technique used to identify organic pigments and inks on manuscripts nevertheless has reported limitations due to the fluorescence bands for some colourants being very broad, causing the emissions of distant chromophores to become difficult to distinguish. Using UV-Vis to detect organic elements can fail to show the degree of detail that is needed for fingerprinting unknown materials [34]. Indeed, the lack of reference samples for calibrating such instrumentation is a hindrance to accurate detection in the artwork.

The use of non-invasive analytical techniques is well established, for example scientists at the Department of Manuscripts and Printed Books at the Fitzwilliam Museum use non-invasive $\mathrm{X}$-ray fluorescence spectroscopy (XRF) and UV-Vis near-IR reflectance spectroscopy for detecting inorganic and organic pigments [32]. Research projects have also made use of a mobile analytical facility provided by MOLAB $^{\circledR}$ combining portable Raman, UV-Vis, XRF and mid-infrared reflection spectroscopy [36].

Other methods, such as FT-IR, Raman, High Performance Liquid Chromatography (HPLC) and Diode Array (DAD), Laser-based ionization techniqueseven though they are considered as scientifically credible-require micro-samples from objects, which can not always be achieved when dealing with manuscripts [33]. According to some scientists, identifying organic dyes on manuscripts is possible when trying to diagnose organic pinks and purple colourants using microspectrofluorimetry, combining Raman Spectroscopy and Surface Enhanced Raman Spectroscopy (SERS), yet micro sampling is needed for these techniques [37]. Even then some researchers state that the full range of pigments can be difficult to detect especially individual components of organic materials, therefore limiting the overall analytical information presented which may be needed [34, 37].

In Krekel's research, he analyzed the fresh ivy gum using gas chromatography-mass spectrometry (GCMS) and Nuclear Magnetic Resonance Spectroscopy techniques (NMR) and found that the main extractable component in the fresh gum was falcarinol $\left(\mathrm{C}_{17} \mathrm{H}_{24} \mathrm{O}\right)$, which is highly reactive and polymerizes in air [19]. This explains why it was not found in the old resinous ivy gum. There is a vast range of other materials listed in the ivy plant's chemical structure which may prove useful in future analyses, for example: a-hederin $\left(\mathrm{C}_{41} \mathrm{H}_{66} \mathrm{O}_{12}\right)$, and alkaloid emetine $\left(\mathrm{C}_{29} \mathrm{H}_{40} \mathrm{~N}_{2} \mathrm{O}_{4}\right)$ which are found in the leaves and the entire plant, with D-galactose $\left(\mathrm{C}_{6} \mathrm{H}_{12} \mathrm{O}_{6}\right)$ present only in the fruit [38].

Whereas these techniques can produce successful results by using combined instruments with the added advancements of mobile equipment, it is acknowledged that identifying organic elements on cultural artefacts can be very challenging due to the chromophoric complexities found in the structure of some organic pigments. Despite the improvements and advancements in current and past analytical practice-which no doubt can be very valuable in particular circumstances-no technique is truly ideal to identify all organic pigments 


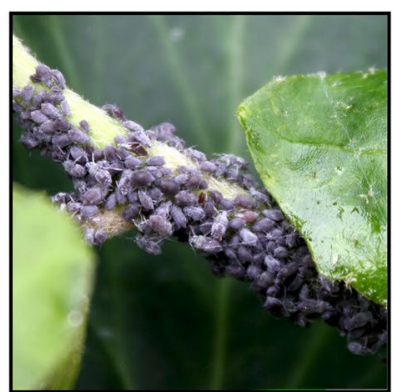

$\mathbf{a}$

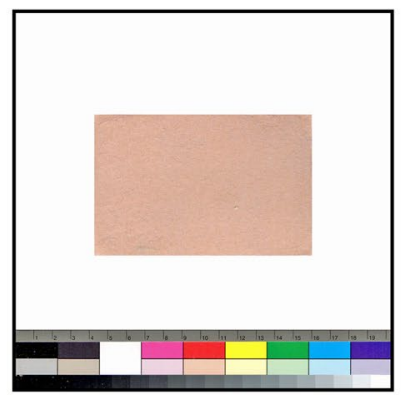

b

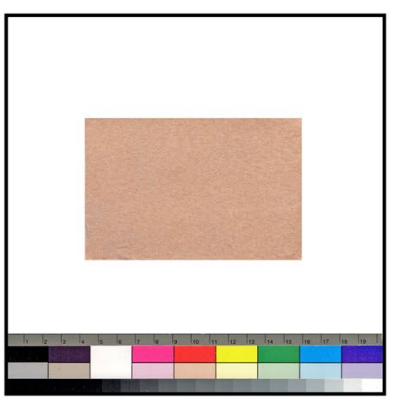

c

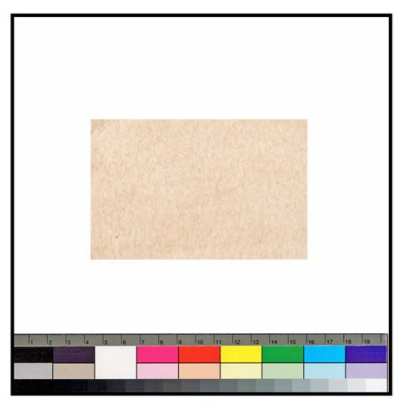

d

Fig. 9 a Ivy aphids. b Fleshly made aphid sample using white wine and alum. c Aphid stain sample after 4 years in a concealed envelope. d The sample were additional exposed to natural daylight for 2 months and had started to fade

on manuscripts or other irreplaceable artefacts, due to the restrictions imposed by the need for micro-sampling of organic pigments and the limitations in detection associated with some of the scientific equipment used for this purpose [33, 34].

\section{Samples using standardized colour reference cards}

When the paint was freshly made, each sample was digitally scanned at $300 \mathrm{dpi}$ with a colour reference card using an Epson XP scanner. Paint samples were then stored in a brown paper envelope in a dark box away from direct light to imitate the conditions of an enclosed manuscript book. Only 1 sample was exposed to daylight for several months to measure the stability in an open environment. After several months, and in some cases 4 years, the paint samples were re-scanned and the results compared with the original digital scans. By this means the colour-fastness and stability of the paint samples could be evaluated, identifying any colour changes in real-time ageing.

The colour reference card used for this work is shown at the bottom of each digital paint image and ensures that the true colour tone can be accurately evaluated when displayed on computer screens anywhere in the world. For example, the hue, saturation, brightness and contrast can be digitally adjusted using Adobe Photoshop to match the actual standardized colour reference card shown on the screen. This allows a comparison with the original scan for each paint sample to be made against its current appearance, thus tracking with some accuracy any colour changes that have occurred naturally over time.

Accelerated ageing techniques (artificial aging) using daylight fluorescent lamps can also be used to produced high levels of light over a fixed period to test photo chemically induced fading and bleaching. Other methods involve exterior exposure under glass or in Xenon-arc lamps that mimic natural sunlight, techniques recommended by ASTM (American Society for Testing Materials) as standard lightfastness testing for industry paints [39].

\section{Results}

The first colour made using the ivy aphid produced a fairly stable flesh-tone stain (Fig. 8, no. 2). While it did show signs of a slight colour change over the period of 4 years in concealed conditions, it maintained an appearance close to the original freshly applied stain. However, the aphid colourant starts to rapidly change when it is further exposed to direct daylight over a period of 2 months (Fig. 9d). The wormwood aphid initially had a similar paint colour to the ivy aphid but changed more, although the change was not pronounced. The giant willow aphid also produced similar shades to that of the ivy aphid, however, when the dye was added to potassium carbonate mixed with calcium carbonate, the colour was unstable; after several months it showed strong colour changes. Ivy gum mixed with calcium carbonate produced a good flesh tone but developed a slight colour change. Ivy rubbery-gum mixed with potassium carbonate with a water-based dye made with giant willow aphid, showed strong signs of colour change becoming unstable after only several months.

\section{Conclusion}

The colour intensity produced by aphid-based dyes appears to be duller in comparison to the dyes from commercially produced scale insects, kermes and cochineal, nevertheless, this work shows that aphid species can produce a workable paint when the dye is mixed with a calcium carbonate substrate or used simply as a dye-based stain. Monitoring changes in the aphid and ivy gum colourants indicated that over 4 years all samples maintained their original colour, but after several months, dye from the giant willow aphid lost its original strength by 
rapidly fading in a concealed environment, therefore, being very unstable.

From the aphids selected for study, colour from the ivy aphid (Aphis hederae) made with wine using similar processes from the fifteenth-century recipe $\$ 8$ without adding any calcium carbonate, has remained fairly stable after 4 years kept in a dark envelope (Fig. 8-no.2). Therefore, using the ivy aphid reconstruction as a basis to work from, the stability of the colour could be developed further using variant recipe combinations with other ingredients. Even with the more fugitive colour from the giant willow aphid, with further research and investigation its durability may be improved by adjusting the processing method and additives.

Despite colour changes, this work demonstrates that ivy gum and the aphid insects are indeed a suitable material source for making dye-based colourants, in particular for paint that replicates flesh tones. This exploration is important for recognizing alternative materials to produce paint at a local level, especially from a creative practitioner's perspective when exploring pinkish paint tones. On a practical level it can offer a good starting point for further investigation into colours produced from other aphid insects. In terms of the historic use of aphid-based and ivy gum dyes, this work provides a set of reference samples which could form the basis of further studies on the range of colourants used in early manuscripts and other cultural heritage objects.

\section{Abbreviations \\ $\S$ : refers to paragraphs in the text of the manuscripts; LDA: Liber diversarum arcium text in the Montpellier, University Library, MS H 277; MS: manuscript.}

\section{Authors' contributions}

The author read and approved the final manuscript.

\section{Authors' information}

The author is a Creative Practitioner and Independent Scholar who explores organic materials documented in historic manuscripts. He focuses on and grows specific plants to investigate potential colourants using past painters' and illuminators' recipes, developing resources for researchers, institutions, and site specific displays. He collaborates with international experts in conservation, the humanities and the scientific community, by sharing penetrative knowledge that opens up numerous ways of seeing to establish a better understanding of the materials explored and researched.

\footnotetext{
Acknowledgements

I gratefully acknowledge support from Mark Clarke, Maria Joao Melo and Leslie Carlyle from the New University of Lisbon; Paola Ricciardi from the Fitzwilliam Museum, Cambridge; Lara Broecke; Christoph Krekel; Collins from Imperial College London; David Kingston, Virginia; Ilaria Degano from the University of Pisa; Royal Botanic Gardens, Kew; Mick Lavelle and Jill Raggett from Writtle University College, Essex; Bob Dransfield from influentialpoints.com; and the constructive criticisms of a number of reviewers that have materially improved this paper. Leslie Carlyle and Paola Ricciardi made a thorough edit to the paper.
}

\section{Competing interests}

The author declares no competing interests.

Availability of data and materials

Not applicable.

Consent for publication

Not applicable.

Ethics approval and consent to participate

Not applicable.

\section{Funding}

There was no funding awarded for this study.

\section{Publisher's Note}

Springer Nature remains neutral with regard to jurisdictional claims in published maps and institutional affiliations.

Received: 14 September 2017 Accepted: 19 June 2018

Published online: 27 June 2018

\section{References}

1. Charles JG, Nef L, Allegro G, et al. Insect and other pests of poplars and willows. In: Isebrands JG, Richardson J, editors. Poplars and willows: trees for society and the environment. Boston: The Food and Agriculture Organization of the United Nations and CABl; 2014. p. 495.

2. Buckton GB. Monograph of the British Aphides, vol. 2. London: Ray Society; 1879. p. 167-70.

3. Sauders D, Kirby J. Light-induced colour changes in red and yellow lake pigments. Natl Gallery Tech Bull. 1994;15:79-97.

4. Kadolph SJ. lowa or Dye! Natural dyes as American craft and horticulture. 2008. https://digitalcommons.unl.edu/tsaconf/252/.Accessed 10 Oct 2017.

5. Cameron DW, Cromartie RIT, Kingston DGl, Todd L. 10. Colouring matters of the Aphididæ. Part XVII. The structure and absolute stereochemistry of the protoaphins. J Chem Soc. 1964. https://doi.org/10.1039/JR96400000 51.

6. Brown KS. The chemistry of aphids and scale insects. Chem Soc Rev. 1975:4(2):263-88

7. Bechtold T, Mussak R. Handbook of natural colorants. Hoboken: Wiley; 2009. p. 6-7.

8. Kirby J, van Bommel M, Verhecken A. Natural colorants for dyeing and lake pigments: practical recipes and their historical sources. London: Archetype Publications; 2014. p. 9-12.

9. Merrifield MP. Medieval and renaissance treatises on the arts of painting: original texts with english translations two volumes bound as one. New York: Dover Publications; 1999. p. 310.

10. Campbell L, Dunkerton J, Kirby J, Monnas L. Two panels by Ercole de' Roberti and the identification of 'veluto morello. Natl Gallery Tech Bull. 2001;22:29-41.

11. Smith CS, Hawthorne JG. Mappae clavicula: a little key to the world of medieval techniques. Trans Am Philos Soc. 1974;64(4):1-128.

12. Collins CM, Leather SR. Effect of temperature on fecundity and development of the Giant Willow Aphid, Tuberolachnus salignus (Sternorrhyncha: Aphididae). Eur J Entomol. 2001;98:177-82.

13. Zadoks JC. Crop protection in medieval agriculture: studies in pre-modern organic agriculture. Leiden: Sidestone Press; 2013. p. 148.

14. Clarke M. Mediaeval Painters' Materials and Techniques: The Montpellier Liber diversarum arcium. London: Archetype Publications; 2011. p. 20, p. 109, p. 118, p. 179.

15. Arn MJ. The emendation of wine: wine recipes from Beinecke MS 163 (" The Wagstaff Miscellany"). Yale Univ Library Gazette. 1990;64(3/4):109-23.

16. Aretaeus, Adams F. The extant works of Aretaeus, the Cappadocian. London: The Syndenham Society; 1856. p. 381.

17. Beck LY. Pedanius Dioscorides of Anazarbus: De Materia Medica. Hildesheim: Olms-Weidmann; 2011. p. 172. 
18. Clarke M. The crafte of lymmyng and the maner of steynyng: Middle English recipes for painters, stainers, scribes and illuminators. Oxford: Oxford University Press; 2016. p. 170.

19. Krekel C, Eichner S, Krüger K. De edera et lacca: identification of a medieval colorant made from ivy. In: Kirby J, editor. The diversity of dyes in history and archaeology. London: Archetype Publication; 2017. p. 139-45.

20. Hunt T. Early Anglo-norman receipts for colours. J Warbg Court Inst. 1995;58:203-9.

21. Alexander JG, Binski P. Age of chivalry: art in Plantagenet England, 1200-1400. London: Royal Academy of Arts; 1987.

22. Van Emden HF, Harrington R. Aphids as Crop Pests. Wallingford: CABl; 2017. p. xxiv.

23. Buckton GB. Monograph of the British aphides, vol. 3. London: Ray Society; 1881 . p. $96-7$

24. Lewington A. Plants for people. New York: Random House; 2003. p. 45.

25. Mills J, White R. The organic chemistry of museum objects. Abingdon: Routledge; 2012. p. 36.

26. Freitag W, Stoye D. Paints, coatings and solvents. Hoboken: Wiley; 2008. p. 355.

27. Rowland ID, Howe TN, editors. Vitruvius: the ten books on architecture. Cambridge: Cambridge University Press; 1999. p. 94-5.

28. Thompson DV, Hamilton GH. An anonymous fourteenth-century Treatise De Arte Illuminandi: the technique of manuscript illumination. New Haven: Yale University Press; 1933. p. 17.

29. Hawthorne JG, Smith CS. Theophilus, on divers arts: the foremost medieval treatise on painting, glassmaking and metalwork. New York: Dover Publications Inc; 1979. p. 15-25.

30. Broecke L. Cennino Cennini's "Il libro dell'arte": a new English translation and commentary with Italian transcription. London: Archetype Publications; 2015. p. 190-3.
31. Neven S. The Strasbourg manuscript: a medieval tradition of artists' recipe collections (1400-1570). London: Archetype publications; 2016. p. 125.

32. Panayotova S, Jackson D, Ricciardi P, editors. Colour: The art \& science of illuminated manuscripts. London: Harvey Miller Publishers; 2016. p. 377, p. 271-303.

33. Clarke M. The analysis of medieval European manuscripts. Stud Conserv. 2001;46(1):3-17.

34. Degano I, Ribechini E, Modugno F, Colombini MP. Analytical methods for the characterization of organic dyes in artworks and in historical textiles. Appl Spectrosc Rev. 2009;44(5):363-410.

35. Bioletti S, Leahy R, Fields J, Meehan B, Blau W. The examination of the Book of Kells using micro-Raman spectroscopy. J Raman Spectrosc. 2009;40(8):1043-9.

36. Anselmi C, Ricciardi P, Buti D, Romani A, Moretti P, Rose Beers K, Brunetti BG, Miliani C, Sgamellotti A. MOLAB ${ }^{\circledR}$ meets Persia: non-invasive study of a sixteenth-century illuminated manuscript. Stud Conserv. 2015;60(sup1):S185-92.

37. Melo MJ, Nabais P, Guimarães M, Araújo R, Castro R, Oliveira MC, Whitworth I. Organic dyes in illuminated manuscripts: a unique cultural and historic record. Phil Trans R Soc A. 2016;374(2082):20160050.

38. Duke JA. Handbook of Phytochemical Constituents of GRAS Herbs and other Economic Plants. CRC Press; 1992. https://phytochem.nal.usda.gov/ phytochem/plants/show/1008?et. Accessed 28 June 2016.

39. Koleske JV. Paint and coating testing manual: fifteenth edition of the Gardner-Sward handbook. Philadelphia: ASTM; 2012. p. 768-9.

40. Berrie BH, Strumfels Y. Change is permanent: thoughts on the fading of cochineal-based watercolor pigments. Heritage Sci. 2017;5(1):30.

\section{Submit your manuscript to a SpringerOpen ${ }^{\odot}$ journal and benefit from:}

- Convenient online submission

- Rigorous peer review

- Open access: articles freely available online

- High visibility within the field

- Retaining the copyright to your article

Submit your next manuscript at $\boldsymbol{\nabla}$ springeropen.com 